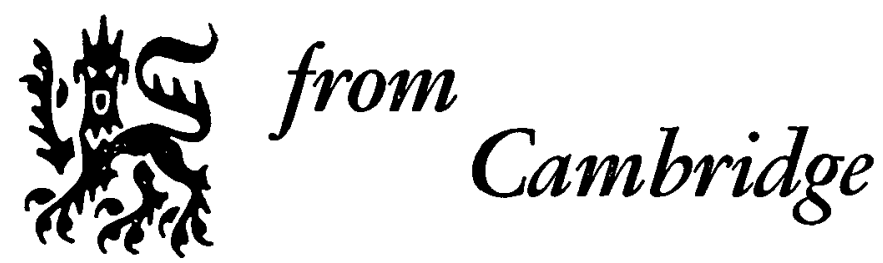

\title{
Japan's First General Election, 1890
}

R. H. P. MASON

A study of the first parliamentary election ever held in Asia, based on contemporary newspapers, state documents and rival party manifestos.

A descriptive and analytical account of the election is introduced by a discussion of the main political trends leading up to the establishment of constitutional government in 1889. The discussion is continued in Dr Mason's conclusion to form a conceptual framework for the election and Meiji political development as a whole.

$\$ 7.50$

\section{Literacy in Traditional Societies}

Edited by JACK GOODY

Studies on the development of literacy and its influence on traditional and pre-industrial societies. Locales include China, India, Thailand, New Guinea and Melanesia; four of the essays discuss African societies and one deals with pre-industrial England.

All the articles except one ("The Consequences of Literacy" by Jack Goody and Ian Watt) were specially written for this book.

\section{Reflections on the Transfer of Power and Jawabarlal Nebru}

Admiral of the Fleet

THE EARL MOUNTBATTEN OF BURMA

The second Jawaharlal Nehru Memorial Lecture

\section{CAMBRIDGE UNIVERSITY PRESS}

32 East 57th Street, New York, N.Y. 10022 


\section{Oxford University Press}

\section{Modern China's Search for a Political Form}

Edited by JACK GRAY, University of Glasgow. This volume is the product of a 1965-66 symposium that examined the historical antecedents of the Communist revolution in China. It brings into closer relationship the research in progress on a number of supporting subjects, thus providing for each separate line of research the broad background which, until now, has not existed in a published work. The contributors are: Jerome Ch'en, Mark Elvin, Martin Bernal, Jean Chesneaux, John Gittings, Sybille van der Sprenkel, James MacDonald, and George Moseley. (Royal Institute of International Affairs.) $\$ 10.50$

\section{Contemporary China, 1962-64}

\section{VOLUME VI}

Edited by E. STUART KIRBY, University of Aston. The period covered in this volume had many marked developments, particularly the economic improvements of 1962, that were strongly sustained and widened in the following years. In these years, the ideological differences between the Chinese and Russian Communist parties developed into more direct forms of confrontation. This volume consists of documentary material dealing with specific current problems present in China during this rapidly changing era.

Paper, $\$ 6.00$

\section{The Etymologies of 3,000 Chinese Characters in Common Usage}

By CHANG HSÜAN, University of Hong Kong. This dictionary traces to the present day the etymologies of some 3,000 Chinese characters, illustrating their evolution from first known forms on bronze and stone, and inscriptions on oracles' bones. "I have the pleasure of recommending Mr. Chang Hsüan's magnificent achievement to all who study Chinese language."-Lo Hsiang-Lin, University of Hong Kong, from the Preface $\$ 16.00$

\section{Revolution in Siam 1688}

\section{TRANSLATION OF THE MEMOIRE OF PËRE DE BEZE}

Translated by E. W. HUTCHINSON. These historical memoirs present the year 1688 A.D., one of revolution in the history of both England and Siam. The kings of both countries, James II and Pra Narai, were dethroned while pro-French policy was reversed, and a severe setback administered to the ambitious aims of Louis XIV to impose Catholicism and French grandeur on the national religions and statehood of both countries. The account of these events is presented around the central figure of Constans Phaulkon, a Greek adventurer.

\section{OXFORD UNIVERSITY PRESS}




\section{GEORGE M. WILSON}

JAMES W. GOULD

\section{VERA MICHELES DEAN}

\section{RADICAL NATIONALIST IN JAPAN}

\section{Kita Ikki, 1883-1937}

The growth of radical nationalism in Japan is revealed through study of one of its chief proponents, Kita Ikki. "Extremely stimulating reading . . . of interest not just to those concerned with modern Japan but also to anyone interested in modern political thought."-Edwin O. Reischauer. Harvard East Asian Series, $87 . \$ 7.00$

\section{THE UNITED STATES AND MALAYSIA}

This volume is the first comprehensive analysis of American-Malaysian relations and Malaysian foreign policy. A discerning examination of Malaysia, Singapore, and Brunei, it focuses on American involvement in the region and the political, cultural, and economic accomplishments of its three divergent races. American Foreign Policy Library. $\$ 6.95$

\section{NEW PATTERNS OF DEMOCRACY IN INDIA}

\section{Second Edition}

Mrs. Dean has expanded and brought up to date her interpretation of India and its future. Summarizing the social, economic, and political progress in India over the last decade, she concludes that India will continue on its path toward democracy, withstanding the threat of Communism. $\$ 5.95$

In Canada/Saunders of Toronto, Ltd. 


\section{Abmedabad}

A Study in Indian Urban History

K. L. Gillion

Ahmedabad, India's sixth city in size and one of the richest, was not a creation of British rule but an old center of trade and industry that adapted to the new age and became "The Manchester of India." Its recovery in the nineteenth century, after a decline in the previous one, contrasted with the experience of other Indian cities, many of which suffered a different fate under British rule.

1969 LC: $68-25943216$ pages illustrations $\$ 7.00$

\section{Politics and Social Conflict in South India}

The Non-Brahman Movement and Tamil Separatism, 1916-1929

\section{Eugene F. Irschick}

Mr. Irschick breaks new ground in this strikingly intimate account of social and political conflict in early twentieth-century India. Although his findings have relevance far beyond Madras Presidency and the period under review, they concern essentially the non-Brahman political movement in South India following the inauguration of the Indian Home Rule movement in 1916.

1969 LC: $68-31595480$ pages $\$ 9.75$

\section{Bureaucrats Under Stress}

\section{Administrators and Administration in an Indian State}

Richard P. Taub

Mr. Taub's book is firmly based in firsthand study, involving interviews with administrators as well as with the people with whom they must work, and examining both the attitudes men bring to their jobs and the nature of their tasks. The author is able to identify the main sources of strain that affect Indian administrators, and to demonstrate how these strains interact and limit potential performance.

1969 LC: $68-58080256$ pages $\$ 6.75$

\section{British Orientalism and the Bengal Renaissance}

The Dynamics of Indian Modernization, 1773-1835

\section{David Kopf}

Mr. Kopf is concerned mainly with the relationship of the Bengal Renaissance to the more general problem posed by the tension that has typically existed between tradition and modernity under British colonial rule. His book illuminates what has heretofore been an obscure area of modern Indian history.

1969 LC: $69-13135352$ pages $\$ 8.50$

\section{The Nadars of Tamilnad}

\section{The Political Culture of a Community in Change}

Robert L. Hardgrave, Jr.

In exploring the structural and cultural changes that the Nadars, a large South Indian caste, have experienced during the past 150 years, Mr. Hardgrave illuminates the interaction between caste and politics characteristic of Indian society. By scrutinizing a community undergoing change in the social and political space between the village and the larger society, he opens up a new perspective and method of analysis.

1969 LC: $69-13726336$ pages $\$ 8.75$ 


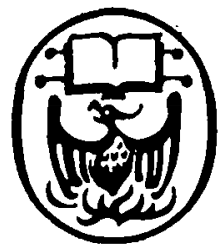

\section{Outstanding Books from The University of Chicago Press}

\section{Krishna: Myths, Rites, and Attitudes}

\section{Edited by Milton Singer}

With a Foreword by Daniel H. H. Ingalls

The cult of the god Krishna has been widespread in India for more than two thousand years. Six scholars join here to examine the steady stream of poetry, legend, myth, and rite which since about A.D. 200 has dramatized the deeds and described the world of Krishna of Gokula - a land where every object if rightly seen is a key to truth and eternity. Contributors are: Thomas J. Hopkins, J. A. B. van Buitenen, Edward C. Dimock, Jr., Surajit Sinha, Milton Singer, T. K. Venkateswaran, S. M. Pandey, Norman Zide, and McKim Marriott.

$$
1969 \text { LC:65-20585 } 277 \text { pages Paper, } \$ 2.95
$$

\section{Village India}

\section{Edited by McKim Marriott}

Preceding from the ideas suggested by Robert Redfield in The Little Community, eight social anthropologists illuminate the caste and community structure, personality, religions, world views, and current forces of social change in eight Indian villages. Based on extensive field work, the papers included in this volume treat villages in seven different linguistic areas and five Indian provinces. Comparative Studies of Cultures and Civilizations series.

1955 LC: $55-9326269$ pages, illus., Paper, $\$ 3.45$

\section{The Modernity of Tradition}

\section{Political Development in India}

\section{Lloyd I. Rudolph and Susanne Hoeber Rudolph}

In this study of modern India, the Rudolphs explore tradition's potential for change and its relationship to an industrializing society. They show that the introduction of political democracy has mobilized and transformed the caste system. A study of Gandhi illumines the nonviolent ideas later adopted by Martin Luther King, Jr. Affinities between tradition and modernity in the areas of social stratification, charismatic leadership, and law are also discussed.

1967 LC: $67-25527 \quad 306$ pages, $\$ 8.75$

\section{Folktales of Japan}

\section{Edited by Keigo Seki}

Translated by Robert J. Adams

With a Foreword by Richard M. Dorson

“. . . the tales in this book are not literary versions but versions recorded from twentiethcentury informants as still alive today. . . . a good representative selection of Japanese folktales (mukashibanashi).-D. E. Mills, Journal of the American Oriental Society. ". ... there will be found in this extensive collection many that are unfamiliar to Japanese as well as Western readers."-The Asian Student. Includes explanatory notes, glossary, index, bibliography, table of tale-types and motifs. Folktales of the World series.

1963 LC: 63-13071 221 pages Cloth, \$5.95 Paper, \$2.95

\section{Village Japan}

\section{Richard K. Beardsley, John W. Hall, and Robert E. Ward}

Now available in paperback, Village Japan is a complete study of a social microcosm in every aspect of its activity and organization. It provides an excellent starting point for an understanding of the people of rural Japan. The Journal of Asian Studies said of its original publication, "Once every twenty years or so a work is likely to appear on a subject of major importance which is so significant in its field that it automatically becomes a standard reference. Village Japan promises to become such a study." 


\section{The Poetry of Li Shang-yin}

\section{A Ninth-Century Baroque Chinese Poet \\ James J. Y. Liu}

Li Shang-yin, considered among the greatest and most fascinating of Chinese poets, is as yet little known in the West. Here one hundred of his poems are translated, most for the first time, with accompanying exegetical notes and commentaries. Historical and biographical information is included, along with various interpretations of Li's work and the author's own critical evaluation. The book well conveys the spirit of the poet, the richness of his work, and the atmosphere of the time in which he wrote.

1969 LC:68-30695 566 pages, $\$ 10.75$

China in the Eyes of Europe: The Sixteenth Century

India in the Eyes of Europe: The Sixteenth Century

Japan in the Eyes of Europe: The Sixteenth Century

Southeast Asia in the Eyes of Europe: The Sixteenth Century

Donald F. Lach

"No scholar before Donald F. Lach has attempted to survey the intricate web of relationships between Europe and Asia at such a level of detail. His book is a masterpiece of comprehensive scholarship" J. H. Plumb wrote in The New York Times Book Review on the publication of The Century of Discovery, the first volume of Asia in the Making of Europe, in 1965. Geoffrey Barraclough, in The New York Review of Books said: "nothing of this scope and magnitude has been performed before, and nothing is likely to be performed again." Unabridged chapters from Part Three of this major work are now available in paperback.

Lach portrays the growth of the spice trade, the invention of printing, and the spread of Jesuit missions during the sixteenth century, and discusses the gradual changes in the legendary character of Asia in European minds. By 1600 there was a body of knowledge derived from the writings of merchant travelers and missionaries and from the printed maps of cartographers. Details of what the literate European could have known, by 1600 , about each individual area comprise the chapters now available as paperbacks, with new prefaces by the author.

Paper, "China" \& "Japan" \$1.45

"India" \& "Southeast Asia" \$1.95

\section{China in Crisis}

\section{Volume 1. China's Heritage and The Communist Political System Edited by Tang Tsou and Ping-ti Ho}

Perhaps more than any other modern country, China offers a unique opportunity to examine the relationship between tradition and modernity, between continuity and change in political and social institutions. This two-volume major work explains both traditional and contemporary China as well as her position in the current crisis in international affairs. The papers assembled here were presented at the inaugural conference (1966-67) of the Center for Policy Study at the University of Chicago. With a foreword by Charles U. Daly.

1968 LC:68-20981 Volume I, 2 books 803 pages, $\$ 20.00$

\section{China in Crisis}

\section{Volume II: China's Policies in Asia and America's Alternatives Edited by Tang Tsou}

The continuing debate in the United States over policies toward China and Vietnam provides a compelling occasion for re-examining the objectives and capabilities of Communist China and her relations with major countries in Asia. This second volume of papers presented at the Center for Policy Study conference discusses China's military strength; her diplomatic opportunities, capacities, and constraints in Asia; her growing contacts with Japan; and three alternative American policies toward China.

1968 LC:68-20981 484 pages, $\$ 10.00$

The University of Chicago Press, Chicago 60637 


\section{G. K. HALL B CO. PUBLICATIONS}

\section{Cumulative Bibliography of}

\section{$\mathbb{A S I A N} \mathbb{S} \mathbb{T} U \mathbb{D} \mathbb{E} S, \quad \mathbb{1 9 4 1 . 1 9 6 5}$ Association for Asian Studies, Inc.}

\begin{abstract}
PREPUBLICATION PRICE AUTHOR CATALOG

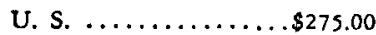

Outside U. S. ......\$302.50

SUBJECT CATALOG

U. S. . . . . . . . . \$290.00

Outside U. S. . .....\$319.00

AFTER OCTOBER 31, 1969 AUTHOR CATALOG

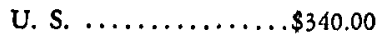

Outside U. S. .......\$374.00

\section{SUBJECT CATALOG}

U. S. . .........\$365.00 Outside U. S. ...... \$401.50

A 5\% discount will be allowed if full payment accompanies order and if order is received by October 31, 1969.

On orders for these publications that total more than $\$ 300.00$, payment may be made in three equal annual installments for an additional $5 \%$.
\end{abstract}

\section{G.K. HALL \& CO. 70 LINCOLN STREET BOSTON, MASSACHUSETTS 02111}

Free catalog of publications on requess
WE ARE PLEASED to publish the Cumulative Bibliography of Asian Studies, 1941-1965. The material for the cumulation has been prepared for publication by the staff of G. K. Hall \& Co.

The Bibliograpby of Asian Studies, under a succession of titles (the Lists of the American Council of Learned Societies' Committee on Far Eastern Studies, Bulletin of Far Eastern Bibliography, Far Eastern Bibliography, Far Eastern Quarterly and Jommal of Asian Studies), has provided bibliographical coverage of the field of Asian studies to a growing number of American (and European) Asian specialists for almost thirty years. During this period the Bibliograpby has increased both in the number of entries and in the areas it covered: the early ACLS Lists were confined to periodical articles on China; the Bulletin included periodical articles on Japan, Korea and other Far Eastern areas, as well as on China; the scope of the Far Eastern Bibliography was expanded to comprise both books and periodical articles on all countries of the Far East and Southeast Asia (1941) and also of South Asia (1955).

At present, the Bibliography of Asian. Studies aims at presenting as complete a listing as possible of significant books and articles in European Janguages concerning the countries of the Far East, Southeast Asia and South Asia in the general fields of philosophy, religion, history, economics, social science, education, language and literature, and political science. To achieve this aim the editors regularly scan the Library of Congress Printed Catalogs and National Union Catalogs, the British, French, German and other national bibliographies, several American and European commercially published bibliographies, as well as the listings and notices appearing in numerous learned journals. In addition, some 700 periodicals devoted to Asian studies, and over 1500 other periodicals of a more general nature are systematically scanned for articles to be listed in the Bibliograpby.

Editorial policy regarding coverage has changed over the years. In the late 1940 's and early 1950 's, coverage was confined largely to periodicals primarily concerned with Asia. During the later 1950's coverage was expanded to include periodicals of a more general nature which were not indexed in the Reader's Guide and International Index. In the 1960's even these "general" periodicals have been covered for articles dealing with Asia.

These catalogs will be reproduced by offset on Permalife paper on pages measuring $7^{\prime \prime} \times 10^{\prime \prime}$. The estimated 85,000 entries in the Author Catalog will be reproduced in four volumes and the estimated 83,000 entries in the Subject Catalog will be reproduced in four volumes. The. volumes will be bound in Class $A$ library binding. 
Valuable Additions for your working libraryMonographs of the

\section{ASSOCIATION FOR ASIAN STUDIES ...}

RESTORATION OF THAILAND UNDER RAMA I, 1782-1809 Vol. XXIV

149 pp.

1968

by Klaus Wenk

$\$ 7.50$

K'ANG YU-WEI: A BIOGRAPHY \& A SYMPOSIUM VOI. XXIII

Edited, with translation by Jung-pang Lo 541 pp.

1967

$\$ 14.50$

A DOCUMENTARY CHRONICLE OF SINO-WESTERN RELATIONS (1644-1820)

792 pp.

1966

Vol. XXII by Lo-shu Fu

$\$ 14.50$

BEFORE AGGRESSION: EUROPEANS PREPARE THE JAPANESE ARMY Vol. XXI

by Ernst L. Presseisen 160 pp.

1965

$\$ 5.00$

SHINRAN'S GOSPEL OF PURE GRACE Vol. XX 97 pp.

by Alfred Bloom $\$ 5.00$

CHIARAIJIMA VILLAGE: LAND TENURE, TAXATION, AND LOCAL TRADE VOI. XIX by William Chambliss 144 pp. 1965 $\$ 5.00$

THE BRITISH IN MALAYA-THE FIRST FORTY YEARS (1786-1826) Vol. XVIII $186 \mathrm{pp}$

1965

by K. G. Tregonning

OF DRIFTING ACROSS

$\$ 4.50$

CH'OE PU'S DIARY: A RECORD OF DRIFTING ACROSS THE SEA VOI. XVII 177 pp. $\quad 1965 \quad$ by John Meskill

KOREAN LITERATURE: TOPICS \& THEMES VOI. XVI $141 \mathrm{pp}$. by Peter $\mathrm{H}$. Lee $\$ 3.75$

REFORM, REBELLION, AND THE HEAVENLY WAY VOI. XV 117 pp.

1964

by Benjamin Weems $\$ 3.75$

THE MALAYAN TIN INDUSTRY TO 1914 Vol. XIV 302 pp. 


\section{Cornell University Press}

"The most important firsthand memoir to come out of the American experience in Viet Nam."

\section{Viet Nam-The Unheard Voices}

By DON LUCE and JOHN SOMMER

With a Foreword by

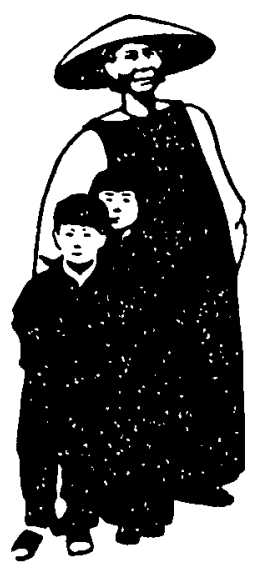
SENATOR EDWARD M. KENNEDY

This is no ordinary book about Viet Nam. Written by two Americans who speak Vietnamese fluently, it reports the words of the people as the authors remember them from many years of living and working in South Viet Nam's hamlets, cities, slums, and refugee camps.

In no other book have the attitudes of the Vietnamese toward the Saigon government, the Viet Cong, or the war's effects on their ancient society been set forth with such insight and documentation. The information on Vietnamese rural life and on the plight of the refugees, Montagnards, and religious groups, combined with discussions of the moral dilemma of American servicemen and the anguish of Vietnamese students, conveys to students and scholars alike the reality of Viet Nam today.

"Don Luce and John Sommer are two extraordinary young men. . . . They and a few others became a part of the [Vietnamese] people, listened to them, spoke for them, worked for them, loved and understood them, at a time when a thoughtless war was rolling over them."

-EDWARD M. KENNEDY, from the Foreword

"The most important firsthand memoir to come out of the American experience in Viet Nam; it is also the most fascinating. . . . Their book is a story of people, of the tragic sympathy the Vietnamese have for Americans despite the suffering our acts have caused, and of the incapacity of Americans to understand the human dimension of the conflict."

- John T. McAlister, JR., author of Viet Nam: The Origins of Revolution 350 pages, photographs, $\$ 6.50$

Cornell University Press ITHACA, NEW YORK 14850 


\section{COLONIALISM VS. NATIONALISM IN ASIA-AN ECONOMIC IMPASSE?}

\section{Underdevelopment and Economic Nationalism in Southeast Asia}

By Frank H. Golay, Ralph Anspach, M. Ruth Pfanner, and Eliezer B. Ayal. The authors show that Southeast Asians are determined to match their hard-won political independence with meaningful economic sovereignty. This book, the product of ten years' field research, examines past and present efforts to transform alien-dominated economies into nationally controlled economies in the Philippines, Indonesia, Thailand, Malaya, South Viet Nam, and Cambodia. Though fully cognizant of the unattractive aspects of economic nationalism, the authors stress the necessity for westerners to understand and adapt to this complex force.

528 pages, 33 tables. $\$ 15.00$

\section{SELF-GOVERNMENT IN TIBET-} THE WAY THINGS USED TO BE

\section{A Tibetan Principality The Political System of Sa sKya}

By C. W. Cassinelit and Robert B. Exvall. Based on extensive interviews with members of the ruling family, this work presents a detailed account of the governmental structure and policy of the Sa sKya principality in west-central Tibet prior to the Chinese invasion. The book examines in detail the correlation between the Sa sKya government and the cultural environment, with emphasis on the belief system of the people, their economy, the geography of their community, their traditions, and the pattern of social deference among them.

464 pages, 7 illustrations, 2 charts, 5 maps. $\$ 15.00$

Cornell University Press

ITHACA, NEW YORK 14850 


\section{New insights into Asia from Praeger}

\section{GENERAL GIAP: POLITICIAN AND STRATEGIST}

By ROBERT J. O'NEILL. This engrossing full-scale study traces the intellectual, political, and military career of the man who was the architect of the stunning victory over the French at Dien Bien Phu and is now Defense Minister and Army Chief of North Vietnam. Giap's personal story sheds new light on topics ranging from Indochinese nationalism in the 1920's to the current Vietnam situation. 250 pp., 12 pp.photogs., 19 maps and diagrams, bibliog., index.

\section{JAPAN SURGES AHEAD}

\section{The Story of an Economic Miracle}

By P. B. STONE. In a "surprise-free" future, Japan may become the second richest nation in the world, despite its few natural resources. In this exciting book, Mr. Stone shows how Japan has achieved high production goals by integrating efficiency, sophisticated technology, and the willing participation of a superb civil service and the world's most highly educated labor force. The modern Japanese economy, he emphasizes, contains lessons for all who hope to abolish world poverty. July. $272 \mathrm{pp}$. $\$ 6.95$

\section{END OF A WAR Indochina, 1954}

By PHILIPPE DEVILLERS and JEAN LACOUTURE. Two noted French experts brilliantly re-create the twelve perilous weeks of battle and negotiation that ended France's days of empire in Indochina, divided Vietnam, and brought the world to the brink of war. Their extraordinarily rich and polished narrative brings the Geneva conference vividly to life, and documents the fateful steps that committed the U.S. to intervention in Vietnam. 424 pp., 2 maps, bibliog., index.

$\$ 8.95$

\section{CHINESE CIVILIZATION} An Introduction

By WERNER EICHHORN. Dr. Eichhorn imaginatively utilizes Chinese sources to present a wealth of unusual materials in this concise, balanced account of Chinese social history and intellectual, literary, and religious development. His text-an ideal introduction to a complex civilization - places major emphasis on the period from prehistoric times to the Mongol invasion of the late thirteenth century. 376 pp., map, tables, bibliog., index. $\$ 9.00$ (cloth); $\$ 3.50$ (paper)

\section{THE POLITICAL THOUGHT OF MAO TSE-TUNG Revised Edition}

By STUART SCHRAM. This major revision adds many of Mao's little known but increasingly relevant early writings, plus major new texts from the past five years. Mr. Schram has also extended the biographicalanalytical Introduction that Guy Wint called (in The Observer) "the most searching, most illuminating document which has yet appeared." May. 464 pp., chronology, 8 maps, bibliog., index.

$\$ 6.50$ (cloth); $\$ 3.95$ (paper)

\section{MAN, STATE, AND SOCIETY IN CONTEMPORARY SOUTHEAST ASIA}

Edited by ROBERT O. TILMAN. In the initial volume in a unique new series, more than thirty of the world's leading specialists focus on the changing societies of nine countries in postwar Southeast Asia-Burma, Cambodia, Indonesia, Laos, Malaysia, North Vietnam, the Philippines, Singapore, and Thailand. The readings, designed specifically for the college student, range from studies of religion and politics to nationhood and national identity. August. ca. 512 pp., maps, charts, appendixes, bibliog., index. ca. $\$ 12.00$ (cloth); ca. $\$ 4.95$ (paper) 


\section{The Concept of Man in Early China}

Donald J. Munro

On the basis of very early Chinese bronze and bone inscriptions, as well as classical texts, the author reaches new conclusions about the ancient Chinese view of man's possibilities and limitations, and his relations with other men and with the universe. The work also serves as a new approach to understanding the nature of early Chinese philosophy as a whole. The crux of early Chinese thought is the idea that men are naturally equal. This doctrine is philosophically more important than the well-known Chinese beliefs in the necessity of social hierarchies and the unequal moral worth of man, and, as the author shows, it is in no way incompatible with them. The book concludes with a discussion of the impact of the idea of natural equality on Chinese intellectual history up to the present day. Illustrated.

$\$ 7.50$

\section{NOW AVAILABLE IN PAPERBACK}

\section{A History of Japan \\ George Sansom}

"The appearance of this volume marks a milestone in the history of Western scholarship on Japan."-The Journal of Asian Studies. "These three volumes represent the mature views of a distinguished historian from the vantage point of a long career in Japanese studies. Written in the elegant and lucid prose that has become for a generation of students the hallmark of Sir George's writing, all three volumes are indispensable for students of Japan." - The Annals. "The trilogy stands as a great, perhaps the greatest, contribution of Western scholarship to the study of the societies of East Asia."-The Western Political Quarterly. Illustrated.

A History of Japan to 1334 . Paper, $\$ 4.95$; cloth, $\$ 10.00$

A History of Japan, 1334-1615. Paper, $\$ 4.95$; cloth, $\$ 10.00$

A History of Japan, 1615-1867. Paper, $\$ 3.45$; cloth, $\$ 8.50$

Order from your bookstore, please

STANFORD UNIVERSITY PRESS 


\title{
New Princeton Paperbacks
}

A SOURCE BOOK IN CHINESE PHILOSOPHY, translated and compiled by Wing-tsit Chan ". . . traces the development of Chinese philosophy and thought from Confucianism to Communism and provides selections from the great Chinese philosophers and thinkers throughout the ancient, medieval, modern, and contemporary periods." The Asian Student \#141\$3.95

CHANGING JAPANESE ATTITUdES TOWARD MODERNIZATION, edited by Marius B. Jansen. First of the volumes in the Studies in the Modernization of Japan series, published for the Conference on Modern Japan of the Association for Asian Studies, Inc. “. . . of significant value to all serious students of Asia . . . particularly relevant to the present situation." Contemporary Japan

SOUTH ASIAN POLITICS AND RELIGION, edited by Donald Eugene Smith. "This admirable volume is a successful attempt to determine the nature of the relationship between Hinduism in India, Islam in Pakistan, and Buddhism in Ceylon." The Asian Student

\#145\$3.95

\section{Princeton University Press \\ Princeton, New Jersey 08540}

\section{A S I A N}

\section{TRANSLATION SERIES}

\author{
Chinese Economic Studies on Chinese Education \\ Chinese Studies in Sociology and Anthropology \\ Chinese Studies in History and Philosophy \\ Chinese Law and Government
}

Chinese Literature and Language*

one Japanese Economic Studies*

The journals in the IASP Asian series, all published quarterly, contain complete and accurate translations of the most significant social sciences and humanities material published originally in mainland China and Japan. The journals provide comprehensive coverage of scholarship and practice in the respective fields for Asian specialists and those who are professionally concerned with related studies.

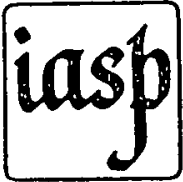

Annual subscription to each journal-Institutions: $\$ 50.00$

Individuals associated with subscribing institutions: $\$ 15.00$

- To appear in Winter 1969

INTERNATIONAL ARTS AND SCIENCES PRESS

901 North Broadway, White Plains, New York 10603 


\title{
VAN NOSTRAND REINHOLD PENETRATES EASTERN POLITICS, HISTORY AND CULTURE...
}

\section{ASIAN POLITICAL SYSTEMS}

Edited by Betty B. Burch and Allan B. Cole, both of Tufts University. 1968, 464 pages, $\$ 5.95$, paper.

A collection of edited readings covering Communist China, Japan, India and Pakistan. The work is distinguished by the fact that the selections are derived exclusively from indigenous sourceslearned journals, books, governmental and party documents, and newspapers of the respective nations. The contributors are Asian politicians, political scientists, historians, sociologists, etc., representing a wide range of disciplines and perspectives. The stress is contemporary, although a few pieces have been selected from earlier post-war years where conditions described continue to prevail. An introductory essay by the editors discusses each political system, and a common analytical framework facilitates comparison.

\section{A SHORT HISTORY OF THE NEAR EAST} Philip K. Hitti, Princeton University. 1966, 288 pages, \$4.75, paper.

A concise historical survey that provides an excellent balance between modern and ancient coverage on the area that currently comprises Turkey, Iran, Iraq, Syria, Lebanon, Jordan, Israel, Egypt and Arabia. This text represents the skillful abridgement of the author's earlier and more comprehensive study, The Near East in History, and contains a wealth of excellent maps, illustrations, photographs, and an invaluable bibliography to help the student gain a firmer understanding of the Near East.

\section{THE ESSENCE OF CHINESE CIVILIZATION}

Edited by Dun I. Li, Paterson State College, Wayne, New Jersey. 1967, 656 pages, $\$ 4.95$, paper.

This selective anthology contains original translations from the works of Chinese authors that cover the broad perspective of Chinese civilization over a period of 3000 years, focusing on four major facets of Chinese life. Part I, Philosophy and Religion, explores the general and specific aspects of Confucianism, Taoism, and Buddhism, as well as several less prevalent schools of thought. Part II, Government, discusses the theory and practice of the various Chinese political systems. Part III, Economics, examines the views expressed by Chinese writers on their nation's material welfare. Part IV, Family and Society, includes readings, often charming and informal, on human relationships, the role of women, the pursuit of pleasure, aristocratic ideals, education and technology.

Send for your on-approval copies. Write College Department,

\section{VAN NOSTRAND REINHOLD CO.}

\author{
300 Pike Street
}

Cincinnati, Ohio 45202 


\section{FORTHCOMING REPRINTS}

\section{FROM THE GREGG INTERNATIONAL ORIENTALIA CATALOGUE}

\section{The Burney Papers}

Printed by order of the Committee of the Vajiranāna national library, Bangkok 1910-14. 15 parts + list of contents reprinted in 5 vols, $4,136 \mathrm{pp}$

New introduction by Dr. D. K. Wyatt Pre-publication $£ 56.5 \$ 135$

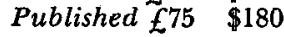

CRAWFURD, John: The Crawfurd papers, a collection of official records relating to the mission of Dr. John Crawfurd sent to Siam by the government of India in the year 1821

Bangkok 1915. 306 pp. Pre-publication $£^{5.5} \quad \$ 12.60$ Published $£ 7 \quad \$ 16.80$

HASAN IBN ALI TĀLIB: The miracle play of Hasan and Husain collected from oral tradition by Colonel Sir L. Pelley, revised with explanatory notes by Arthur N. Wollaston London 18792 vols, 696 Pp. Pre-publication $£ 10.10 \$ 25.20$ Published $£ 14 \$ 33.60$

THEVENOT, Jean de: The travels of Monsieur de Thevenot into the Levant.

In three parts, viz. into: I Turkey. II Persia. III The East Indies. Newly done out of French (A. Lovell)

London 1687. 652 pp. +4 plates Pre-publication $£ 15.10 \$ 37.20$ Published $£ 20 \$ 48$

A full catalogue including many titles already published is available on request.

Orders for the titles listed above at the reduced pre-publication prices shown may be placed now with your bookseller or with:

\section{GREGG INTERNATIONAL PUBLISHERS LIMITED \\ WESTMEAD FARNBOROUGH HAMPSHIRE ENGLAND}

\section{ASIAN SURVEY}

Leading American monthly devoted exclusively to current developments in Asia. Coverage of political, economic and social trends in such societies as Communist China, India, Japan, Pakistan, Korea, Indonesia, Thailand and Burma.

Recent articles have analyzed such topics as Maoist Military Doctrines, Financial Policy in Postwar Thailand, The Pakistan-U.S. Alliance, Viet Cong Tactics, The Mekong Scheme, North Korea's Russian Faction, The Politics of Federalism in Eastern Malaysia, and Indian Socialist Parties in the 1967 Election.

Special coverage is provided at intervals, e.g., the issues on Asian Agricultural Prospects (March 1968), Modernization in South Asian Studies (July 1968), and Japanese Research in Southeast Asia (October 1968). Each year two structured issues are published in January and February surveying trends for the previous year in some 20 Asian countries.

Rates: $\$ 10$ per year for 12 issues ( $\$ 11$ for overseas subscribers). Special student rate: $\$ 5$ per year ( $\$ 6$ overseas). ASIAN SURVEY, University of California, 2234 Piedmont Avenue, Berkeley, California 94720. 


\title{
MICHIGAN PAPERS IN CHINESE STUDIES
}

A publication of the Center for Chinese Studies at the University of Michigan

Articles and longer studies on all aspects of Chinese society, including translations and commentaries in literature and the arts and research analyses in language, history and the social sciences.

No. 1: The Chinese Economy, 1912-1949 by Albert Feuerwerker. (April 1968)

No. 2: The Cultural Revolution: 1967 in Review by Michel Oksenberg, Carl Riskin, Robert Scalapino, and Ezra Vogel. (July 1968)

No. 3: Two Studies in Chinese Literature by Li Chi and Dale Johnson. (November 1968)

No. 4: Early Communist China: Two Studies by Ronald Suleski and Daniel Bays. (February 1969)

No. 5: The Chinese Economy, ca. 1870-1911 by Albert Feuerwerker. (April 1969)

No. 6: (Special Issue: \$3.50) Chinese Paintings in Chinese Publications, 1956-1968: An Index and Annotated Bibliography to the Paintings by $\mathrm{E}$. J. Laing. (June 1969)

each issue- $\$ 1.50$ (excluding special issues)

To order or to be notified of future issues, write:

\author{
Center for Chinese Studies \\ University of Michigan \\ Lane Hall \\ Ann Arbor, Michigan 48104 U.S.A.
}

\section{THE DEVELOPING ECONOMIES}

\section{Quarterly Journal}

of

The Institute of Asian Economic Affairs

42, Ichigaya-Hommura-chō, Shinjuku-ku

Tokyo, Japan

Volume VI

September 1968

Number 3

Two Aspects of the Export of Manufactured Goods

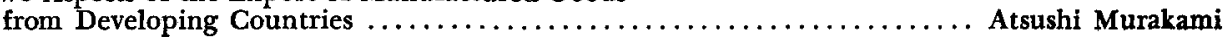

Sarit and Thailand's "Pro-American Policy" $\ldots \ldots \ldots \ldots \ldots \ldots \ldots \ldots \ldots \ldots$ Tōru Yano

Traditional and Modern Industries in India $\ldots \ldots \ldots \ldots \ldots \ldots \ldots \ldots$ Masanori Koga

An Econometric Analysis of the Indonesian Economy .............. Takao Fukuchi

Macro Economic Effects of Foreign Aid .................. Shōichi Yamashita

BOOK REVIEWS

Subscription price (4 issues): $\$ 9.00$ (post free)

Single copies: Ordinary issue $\$ 2.00$;

Special issue $\$ 3.50$ (post free)

Orders may be sent to the sole agent:

MARUZEN COMPANY, LTD.,

P.0. Box 605, Tokyo Central, Tokyo, Japan 


\section{URDU}

\section{Readings in Literary Urdu Prose}

By G. C. Narang

An intermediate text comprising selections from literary Urdu prose and excerpts from newspapers. ". . . a very good and useful work."-Dr. Zakir Husain, President of India "The book fills a great need in our system of Urdu teaching materials. The choice of materials is very good indeed, well graded and well glossed."-M.A.R. Barker, McGill University 396 pages

\section{LAND CONTROL AND SOCIAL STRUCTURE IN INDIAN HISTORY}

Edited by Robert Eric Frykenberg

In the essays in this volume, nine distinguished historians of India reassess what is perhaps the central problem in Indian history. Contributors: Bernard S. Cohn, Ainslie T. Embree, Robert Eric Frykenberg, S. Nurul Hasan, Thomas R. Metcalf, Nilmani Mukherjee, Walter C. Neale, Tapan Raychaudhuri, and Burton Stein. 292 pages

$\$ 10.00$

\section{A CEREMONIAL OX OF INDIA}

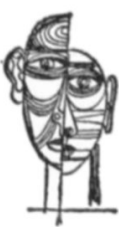

The Mithan in Nature, Culture, and History-With Notes on the Domestication of Common Cattle

By Frederick J. Simoons

“. . . an important contribution. First, it is the only work to provide an accurate and comprehensive account of the mithan in the Assam hill border societies. Second, it provides a useful sketch and detailed bibliography of the main cultural-ecological types to be found in that region ... The scholarship is unimpeachable."-David E. Sopher, Syracuse University 340 pages, 4 illus., 9 maps

At your bookseller or wrile direct.

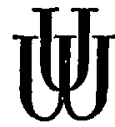

THE UNIVERSITY OF WISCONSIN PRESS BOX 1379

MADISON, WISCONSIN 53701

\section{COMMUNIST CHINA The Domestic Scene: 1949-1967 by}

Peter Tang and Joan Maloney

cloth, $\$ 10.00$

Also Available:

C. Y. Cheng, Communist China's Economy, 1949-1962 cloth, $\$ 5.00$

Mandarin Chinese Dictionary Series

English-Chinese

Chinese-English paper, $\$ 5.50$ ea.

Chinese Language Textbook Series

Three Sets, Twelve Volumes

SETON HALL UNIVERSITY PRESS, South Orange, N. J. 


\section{Beginning Korean}

\section{by Samuel E. Martin and Young-Sook C. Lee}

A model of structural linguistic analysis as well as a teaching tool, this text gives the student a comprehensive grasp of the essentials of modern Korean in 25 lessons, with 5 review lessons, leading to advanced levels of proficiency. Each lesson contains basic sentences, grammar notes with additional examples, exercises, comprehension practice, and conversation guides. The course follows the overall pedagogical methods that have come to be known as the Yale audio-lingual approach.

cloth $\$ 15.00$; papercover $\$ 8.75$

\section{A Korean-English Dictionary}

\section{by Samuel E. Martin, Yang Ha Lee, and Sung-Un Chang}

Emphasizing the native Korean vocabulary, this new dictionary also includes com. monly used Chinese and European loanwords. For the more important entries, the authors provide copious but concise examples to illustrate both meaning and gram. mar. Detailed explanations and examples are given for all particles and endings, and there are also entries for each of the shorter inflected forms that might be confused with some other word.

$\$ 35.00$

\section{Advanced Chinese Reader}

\section{by John DeFrancis}

A sequel to Beginning Chinese Reader and Intermediate Chinese Reader, this text is closely correlated with the author's Advanced Chinese and Character Text for Advanced Chinese. It contains 400 new characters, some 3,000 compounds, and about 20,000 characters of running text. All compounds appear in illustrative sentences and in narrative or expository materials, including adaptations of articles and stories by Chinese authors.

cloth $\$ 15.00$; papercover $\$ 6.75$

Volumes in the series: Beginning Chinese, Character Text for Beginning Chinese, Beginning Chinese Reader, Intermediate Chinese, Character Text for Intermediate Chinese, Intermediate Chinese Reader, Parts I and II; Advanced Chinese, Character Text for Advanced Chinese, Advanced Chinese Reader; Index (forthcoming).

\section{Dictionary of Spoken Chinese}

\section{compiled by the Staff of the Institute of Far Eastern Languages, Yale University}

A major tool for advancing the learning of the language, this dictionary is a lexical and grammatical guide to modern spoken Chinese. Including some 10,000 entries, with examples of usage, it is the first such aid published since the smaller War Department dictionary of 1945, of which it is the authorized revision and expansion.

$\$ 15.00$

Yale University Press




\section{ANNOUNCEMENT}

The Twenty-Second Annual Meeting of the Association for Asian Studies will be held at the Sheraton-Palace Hotel, San Francisco, April 4-6, 1970.

The Twenty-Third Annual Meeting of the Association for Asian Studies will be held at the Washington Hilton Hotel, Washington, March 29-31, 1971. 


\section{Advaita Vedānta:}

\section{A Philosophical Reconstruction}

\section{BY ELIOT DEUTSCH}

Advaita Vedānta is the most important philosophical system in India. It involves a discipline of spiritual experience as well as a technical philosophy, and since the time of Samkara in the ninth century some of the greatest intellects in India have contributed to its development.

In his reconstruction of Advaita Vedānta, Eliot Deutsch has lifted the system out of its historical/cultural context and has concentrated attention on those ideas which have enduring philosophical value. His reconstruction is "the attempt to formulate systematically one's understanding of what is of universal philosophical interest in it." His work covers the basic metaphysical, epistemological, and ethical ideas of Vedānta.

Students and scholars of Western as well as of Indian philosophy will be interested in the lucid, organized manner in which the material is presented and in the fresh interpretations given. The book is written in a critical rather than simply "pious" spirit and should thus also be of interest to anyone concerned to deepen his appre. ciation and understanding of the richness of Indian thought.

$\$ 6.00$

\section{PUBLISHED}

Ways of Thinking of Eastern Peoples: India, China, Tibet, Japan by Hajime Nakamura, Edited by Philip P. Wiener paper $\$ 4.95$ cloth $\$ 12.50$

Intelligibility and the Philosophy of Nothingness by Kitarō Nishida

cloth $\$ 5.50$

Edited by Charles $A$. Moore

The Indian Mind: Essentials of Indian Philosophy and Culture

The Chinese Mind: Essentials of Chinese Philosophy and Culture

The Japanese Mind: Essentials of Japanese Philosophy and Culture

each volume paper $\$ 3.95$ cloth $\$ 9.50$

\section{East-West Center Press - honolulu 96822}

Cultural and Technical Interchange through Books 